\title{
https://doi.org/10.46813/2021-136-165 \\ MODELS, METHODS, AND TECHNOLOGIES FOR CALCULATION OF CHARACTERISTICS OF THE PHYSICAL FACILITY URAGAN-2M
}

\author{
S.O. Martynov, O.O. Luchaninov, V.P. Lukyanova, M.A. Khazhmuradov, S.I. Prokhorets \\ National Science Center "Kharkov Institute of Physics and Technology", Kharkiv, Ukraine \\ E-mail: khazhm@kipt.kharkov.ua
}

\begin{abstract}
Models, methods, and algorithms for three-dimensional modeling of the screw winding of the Uragan-2M torsatron are considered. The application of the method of kinematic modeling is substantiated as the most acceptable for obtaining solid-state and surface models of elements of a magnetic system. Methods for calculating the stresses and strains arising in the elements of the magnetic system of a screw winding under the influence of ponderomotive forces are presented, which makes it possible to determine the strength of the structural elements of the facility.
\end{abstract}

PACS: $52.55 . \mathrm{Hc} ; 52.65 . \mathrm{Kj}$

\section{INTRODUCTION}

The Uragan-2M (U-2M) stellarator toroidal magnetic system is a complex technical object designed to contain a high-temperature plasma with specially created magnetic field. This system belongs to the type of magnetic traps - torsatrons, a characteristic feature of which is the unidirectional movement of currents along the conductors of the poles of the screw winding (SW) [1]. Experimental studies of the magnetic configuration of the torsatron identified a number of problems, the solution of which depends on the calculations of the stressed-deformed state of the elements of the magnetic system.

These tasks include:

- determination of the extreme values of the currents in the conductors of the SW poles at which deformations occur, leading to significant disturbances in the magnetic configuration of the physical facility;

- calculation of the absolute values of the forces that generate such deformations;

- determination of stresses in the elements of the magnetic system, at which they reach the yield point.

Methods for calculating stresses and strains occuring in the elements of the magnetic system of an SW under the influence of ponderomotive forces are presented. The basis of such calculations is a three-dimensional geometric model of the U-2M magnetic system, built using mathematical models, methods and technologies. These include:

- object-oriented analysis for dividing the torsatron into subsystems and connections between them;

- methods of analytical geometry and computational mathematics for obtaining geometric models of objects of complex spatial shape - SW poles;

- the method of finite element analysis for the construction of volumetric and SW surface models.

For the successful use of these methods, it is necessary to take into account the design features of the $\mathrm{U}-2 \mathrm{M}$, which directly determine the system of restrictions on the controlled parameters.

\section{STATEMENT OF THE PROBLEM}

The magnetic system of a torsatron consists of a number of windings, the most complex of which is the SW. It is characterized as an object of complex spatial shape and large overall dimensions - two-lead, provid- ing four periods of the magnetic field. This means that in a sector bounded by a right angle composed of meridional sections of the torus, the SW geometry is uniquely determined (Fig. 1). The number of conductors in a SW pole is twenty.

The cross-section of the conductor has a trapezoidal shape with dimensions $20 \times 24 \times 100 \mathrm{~mm}$. The geometrical characteristics of the SW are set by a set of meridional sections of the torus every $0.5^{\circ}$ when going around the main axis of the torus. The magnetic system of the torsatron also includes a number of flat annular windings, the planes of which are located perpendicular to the main axis of the torus.

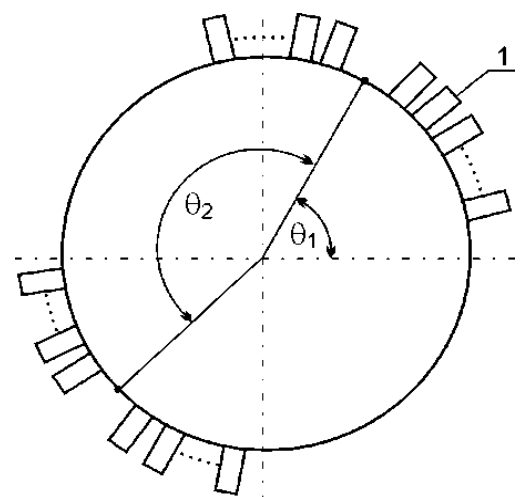

Fig. 1. The meridional section of the SW poles: 1 -conductor at the $S W$ pole;

$\theta_{1}$ and $\theta_{2}$-the angles of the center of the pole

\section{METHODS OF THE GEOMETRIC MODELING OF SW}

To obtain a mathematical model of the SW geometry, the kinematic modeling method $[2,3]$ was used. The essence of the method is that the shaping of the surface of the poles of the magnetic windings of the torsatron is formed when a plane curve moves in space, the shape of which either changes according to a known rule or remains unchanged in the process of movement. Thus, to specify the kinematic surface of the SW, it is necessary to specify a family of plane curves and the law of variation of a plane curve in space.

Let $\psi_{\mathrm{i}}(\mathrm{V})$ - a family of plane curves depending on a parameter $U$ and belonging to a fixed plane $R_{0}^{2}$. $\mathrm{T}_{\mathrm{i}}: \mathrm{R}_{0}^{2} \rightarrow \mathrm{R}^{3}$ - family of maps of this plane in space. In 
this case, the surface of the SW pole is given by the composition of the mappings

$$
\psi(\mathrm{U}, \mathrm{V})=\mathrm{T}_{\mathrm{i}} \psi_{\mathrm{i}}(\mathrm{V}),
$$

where $\mathrm{U}, \mathrm{V}$ - the curvilinear coordinates of the surface.

For a specific case of SW production, the contour of plane curves defines a surface in the form of a set of sections. In this case, the SW surface is represented as a changing curve moving in space, by turns taking the form of meridional sections. In this case, between the sections, the surface is interpolated by linear segments connecting the characteristic points of structural elements on adjacent sections.

Thus, the surface of the SW poles can be represented in the form of a grid (raster) consisting of elements generating lines and segments connecting adjacent generating lines of the vertices of the conductors of the poles of the magnetic windings. With such a representation of the modeled surface, the coordinates of the raster vertices are uniquely determined in the selected coordinate system. If it is necessary to determine the coordinates of points on the modeled surface that are outside the vertices of the raster, the Bezier splines are used [4].

To restore the surface according to Bezier, in each cell of the SW raster, it is necessary to add twelve more points to the existing four raster points so that each cell has sixteen reference nodes. These sixteen nodes are used to construct an approximating Bezier surface for the cell. The advantage of the kinematic method of defining the surface in comparison with other methods using tightening of the corset of the surface created by generating lines and guiding lines is that in this case, to describe a surface of a complex shape (in our case, the surface of the SW), a significantly smaller number of intermediate sections is required due to additional control capabilities of the section plane. In this case, the method takes into account many factors necessary in the design process, in particular, simplicity of description, storage and editing costs, presentation efficiency for a specific SW, stages of technological equipment, intuitive ideas of developers, etc.

\section{METHOD OF FINITE ELEMENT ANALYSIS}

The finite element method (FEM) [5] occupies a leading position in solving problems of solid mechanics due to the possibility of modeling a wide range of objects and phenomena. Popular alternative methods - the finite difference method and the boundary element method (boundary integral equations) now occupy rather narrow niches, limited to research or special problems.

When constructing the geometry of the U-2M magnetic system the FEM is based on the discretization of the SW volume in order to solve the equations of continuum mechanics under the assumption that the relations are fulfilled within each of the elementary regions. Such elements correspond to the real part of the SW space (Figs. 2-4).

Designations in the figures: $\xi, \varphi, \eta$ - element local coordinate system; X,Y,Z - SW global coordinate system; $u, v, w$ - displacements in the local coordinate system for the shell element; $\theta_{\xi}, \theta_{\varphi}, \theta_{\eta}-$ angles of ro- tation relative to local axes at the node and in the global coordinate system $\mathrm{U}, \mathrm{V}, \mathrm{W}$.

Within the FE VO, the properties of the object are assigned - the characteristics of the rigidity and strength of the material (copper conductors of the SW poles) and the fields of the quantities of interest - displacements, deformations and stresses - are described.

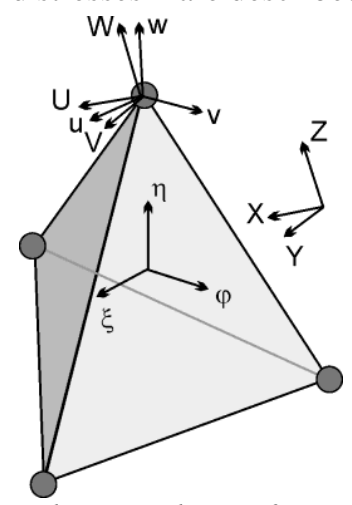

Fig. 2. Volumetric linear finite element

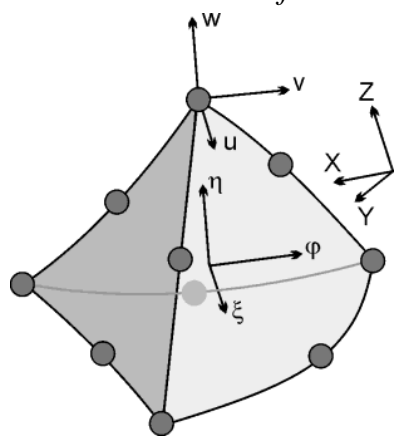

Fig. 3. Volumetric parabolic finite element

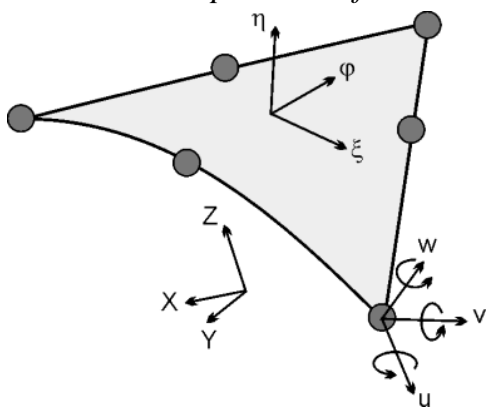

Fig. 4. Parabolic finite element of the surface

Displacements, deformations and stresses are assigned at the nodes of the element, and then interpolation functions are introduced, with the help of which the corresponding valuescan be calculated at any point within the SW element or at its boundary. The mathematical description of an element is reduced to linking the factors acting at the nodes: displacements and forces. Such a sequence of actions in describing the displacements and forces arising in the U-2M magnetic system is sequentially implemented.

The problem is solved by the direct search method under the assumption of a linear problem statement:

1. The displacement field $\Delta$ within the SW element (for a volumetric problem $\Delta=[\mathrm{u}, \mathrm{v}, \mathrm{w}]^{\mathrm{T}}$ ) by means of interpolation functions forming a matrix $[\mathrm{N}]$ is expressed in terms of angular displacements $\{\Delta\}$. The use of interpolation functions provides displacement values at any point of the SW element, depending on the coordinates 
and displacement values at the nodes. In matrix form, the relations have the form

$$
\Delta=\mathrm{N} \cdot\{\Delta,
$$

where $\{\Delta\}=\left[\mathrm{u}_{1}, \mathrm{v}_{1}, \mathrm{w}_{1}, \mathrm{u}_{2}, \mathrm{v}_{2}, \mathrm{w}_{2}, \ldots, \mathrm{u}_{\mathrm{k}}, \mathrm{v}_{\mathrm{k}}, \mathrm{w}_{\mathrm{k}}\right]^{\mathrm{T}}-$ for the volumetric problem of modeling the $\mathrm{SW}$ poles of the $\mathrm{U}-2 \mathrm{M}$ torsatron, $\mathrm{k}-$ is the number of nodes of the finite element.

2. The deformation field $\varepsilon$ is expressed in terms of the degrees of freedom $\{\Delta\}$ by deforming the displacement field according to the relationships forming the matrix [D] and connecting deformations with SW displacements $\varepsilon=[\mathrm{D}] \cdot\{\Delta\}$.

3. Taking into account the equations of state, which are based on Hooke's law and whose coefficients form a matrix [E], a relation is established first between the stress field and the deformation field $\sigma=[\mathrm{E}] \cdot \varepsilon$, and then between the states of freedom at the FE nodes into which the volume of the poles of the magnetic winding of the torsatron is divided $\sigma=[\mathrm{E}] \cdot[\mathrm{D}] \cdot\{\Delta\}$.

4. Expressions are formed for the forces $\{F\}$ acting at the vertices of the element, depending on the stress field $\sigma$, for which the matrix of transformation of stresses into nodal forces $[\mathrm{A}]$ is used $\{\mathrm{F}\}=[\mathrm{A}] \cdot\{\sigma\}$.

5 . The relations between the nodal forces and displacements in the nodes of the torsatron SW are found $\{\mathrm{F}\}=[\mathrm{k}] \cdot\{\Delta\}$, where $[\mathrm{k}]=[\mathrm{A}] \cdot[\mathrm{E}] \cdot[\mathrm{D}]-$ the stiffness matrix of the finite element.

6 . To give the matrix [k] the property of symmetry, we replace the stiffness transformation matrix with the matrix transformed to the displacement-to-deformation transformation matrix $[\mathrm{D}]$. Then $[\mathrm{k}]=[\mathrm{D}]^{\mathrm{T}} \cdot[\mathrm{E}] \cdot[\mathrm{D}]$.

The given dependences allow, knowing the displacements in the SW nodes, to obtain the values of the forces, as well as to solve the inverse problem - to find displacements by forces. The direct formulation is used to obtain the FE stiffness matrices, as well as to describe the heat transfer process in the conductors of the SW of the U-2M torsatron.

To obtain the stiffness matrices of the spatial elements of the SW poles, variational principles are used, in particular, the principle of the minimum potential energy. The stiffness matrix obtained in this way is calculated by the relation

$$
[\mathrm{k}]=\left[\int_{\mathrm{V}}[\mathrm{D}]^{\mathrm{T}}[\mathrm{E}][\mathrm{D}] \mathrm{dxdydz}\right]
$$

The problem of integration over the volume of a body of complex shape or, in the case of a shell element, over curved surfaces, is solved due to the fact that expressions are written in the local coordinate system associated with the element $\xi, \varphi, \eta$, and the coordinates change in the interval $[-1,+1]$. In this case, the expressions for the elementary volume of the SW pole take the form

$$
\mathrm{dxdydz}=|\mathrm{J}| \mathrm{d} \xi \mathrm{d} \varphi \mathrm{d} \eta,
$$

where $|J|$ is the determinant of the Jacobi matrix, then

$$
[k]=\left[\int_{-1}^{+1} \int_{-1}^{+1+1} \int_{-1}^{+}[D]^{T}[E][D] \operatorname{det}[J] d \xi d \varphi d \eta\right] .
$$

Analytical calculation of integrals in the expression for the stiffness matrix isimpossible for triangular FE with curved sides. Therefore, numerical integration is used. Its essence lies in the fact that the integration is replaced by the summation of the products of the integrands calculated in a certain system of points. This process is accompanied by the calculation of the Jacobian determinant. A negative value is a consequence of the degeneracy of this finite element.

Using the method of kinematic modeling, considered in detail in the article, three-dimensional models of the geometry of the magnetic system of the SW of the $\mathrm{U}-2 \mathrm{M}$ torsatron were obtained. The calculation and simulation results are shown in Figs. 5 and 6.

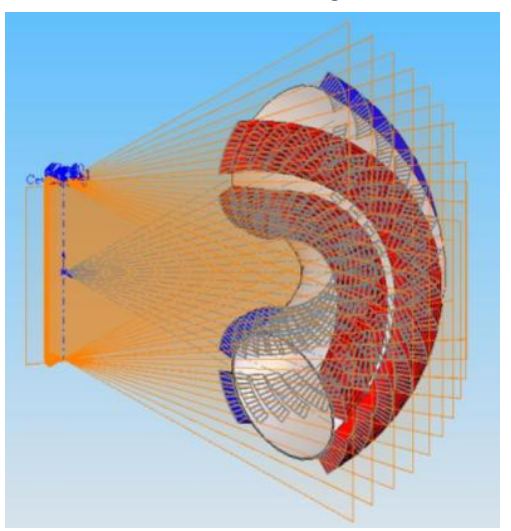

Fig. 5. Three-dimensional model of $U-2 M S W$ on the field period

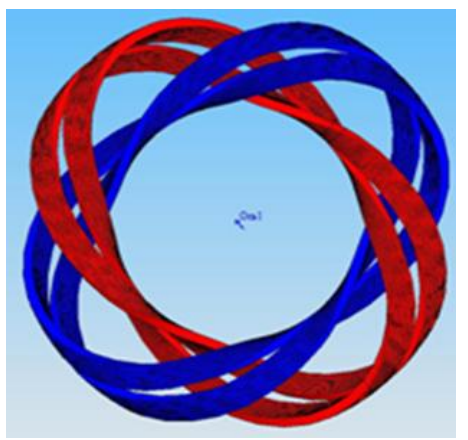

Fig. 6. Three-dimensional model of $U-2 M S W$

\section{MATHEMATICAL MODELS FOR CALCULATING FORCES}

The nature of the origin of ponderomotive forces is based on two experimentally established facts - a magnetic field acts on moving charges and moving charges create a magnetic field.

These two facts underlie the law of Ampere and BioSavard, which are used to obtain mathematical models for calculating forces in the structural elements of the U-2M magnetic system [5].

The force $\mathbf{F}_{\mathbf{m}}$ acting on a moving charge $\mathrm{q}$ in the magnetic field of the facility is expressed by the formula

$$
\mathbf{F}_{\mathrm{m}}=\frac{\mathrm{q}}{\mathrm{c}}[\mathbf{v B}] \text {, }
$$

where $\mathbf{B}$ is the vector of the magnetic field strength in which the charge q moves. The force $\mathbf{F}_{\mathbf{m}}$ is perpendicular to both the electron velocity $\mathbf{v}$ and the vector $\mathbf{B}$, and the magnitude of the force $\mathbf{F}_{\mathbf{m}}$ is proportional to the sine of the angle between the vectors $\mathbf{B}$ and $\boldsymbol{v}$. The value of the constant $\mathrm{c}$ determines the system of units of measurement. 
For practical assessments of the forces arising in the structural elements of the torsatron, it is important to take into account the electric currents in the poles of the windings. In this case, the current created by moving electrons with charge e and concentration $n$ is described by the relation $\mathbf{j}=$ nev .

The number of particles in the volume $\mathrm{dV}$ will be $\mathrm{dN}=\mathrm{nd} \mathrm{V}$, and the force $\mathrm{d} \mathbf{F}$ acting in a magnetic field on an element of volume $\mathrm{dV}$ will be

$$
\mathrm{d} \mathbf{F}=\frac{\mathrm{e}}{\mathrm{c}}[\mathbf{v B}] \mathrm{dN}=\frac{\mathrm{ne}}{\mathrm{c}}[\mathbf{v B}] \mathrm{dV} .
$$

After transformations

$$
\mathrm{d} \mathbf{F}=\frac{1}{\mathrm{c}}[\mathbf{j B}] \mathrm{dV} .
$$

For the calculations of the stress-strain states of the facility, quantitative estimates of the forces are important for both volumetric (vector $\mathbf{j d} \mathbf{V}$ ) and linear $(\mathbf{j d l})$ current elements. If $\mathbf{j d V}=\mathrm{Id} \mathbf{l}$, then

$$
\mathrm{d} \mathbf{F}=\frac{1}{\mathrm{c}}[\mathrm{d} \mathbf{l} \mathbf{B}] \text {. }
$$

Here the direction of the vector $\mathrm{dl}$ coincides with the direction of the current I (Fig. 7).

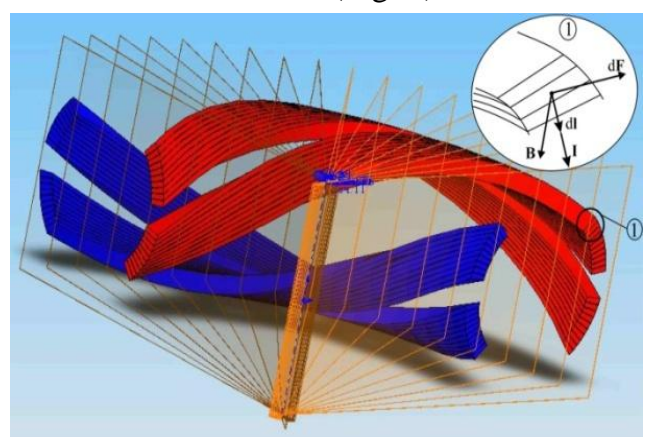

Fig. 7. Vector representation of the calculation of the forces acting on the current element
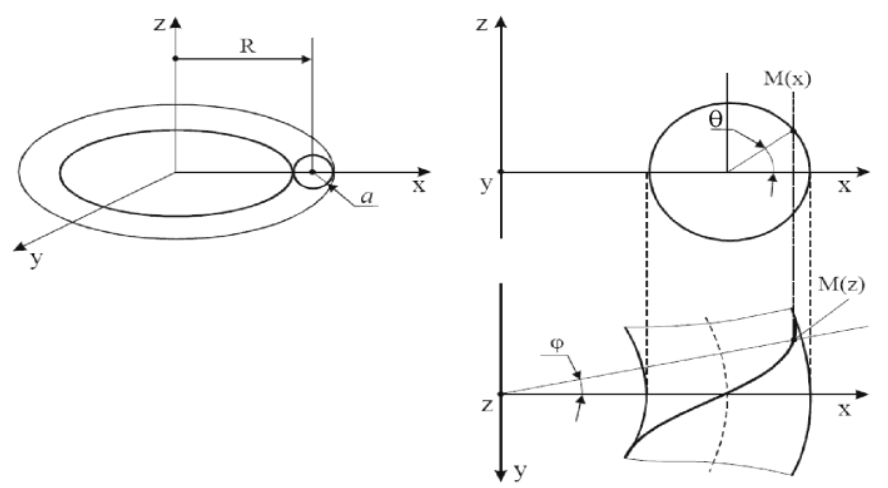

Fig. 8. Coordinate system. $M$ - point belonging to the screw conductor
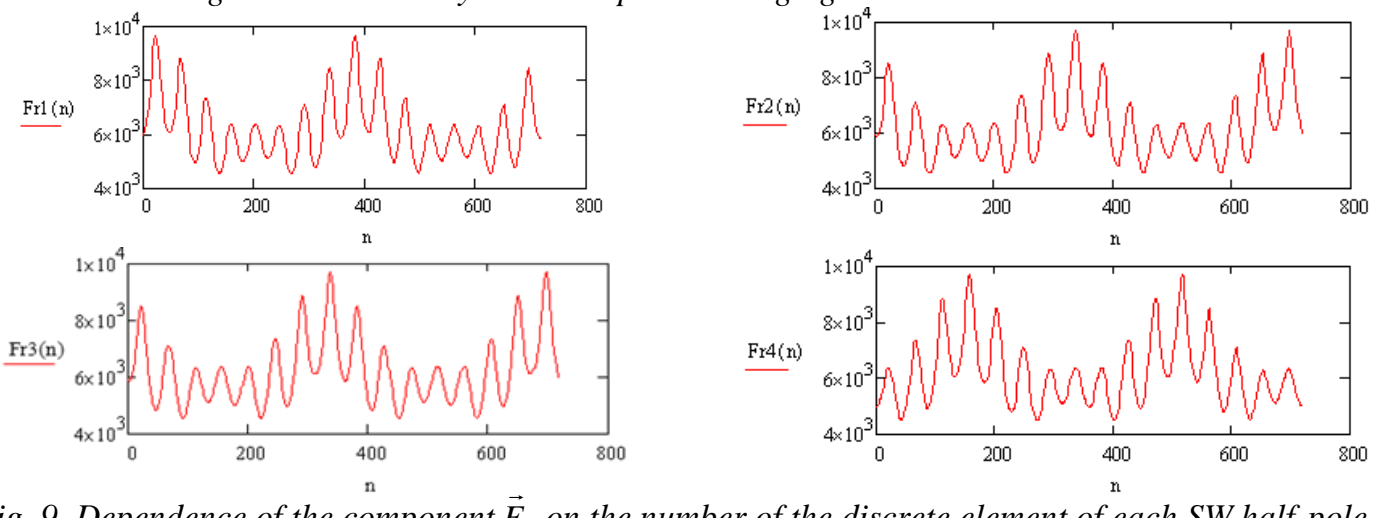

Fig. 9. Dependence of the component $\vec{F}_{r}$ on the number of the discrete element of each SW half-pole

The force acting in the magnetic field of the torsatron on the linear element of the conductor is determined by integration over the entire length of the conductor

$$
\mathbf{F}=\int \frac{\mathrm{I}}{\mathrm{c}}[\mathrm{d} \mathbf{l} \mathbf{B}]
$$

The magnitude of the vector $\mathbf{B}$ in relation (2) is defined as

$$
\mathrm{d} \mathbf{B}=\frac{1}{\mathrm{c}} \frac{[\mathrm{jr}]}{\mathrm{r}^{3}} \mathrm{dV} .
$$

Formula (3) is valid for a volumetric current lement. For line element

$$
\mathrm{d} \mathbf{B}=\frac{\mathrm{I}}{\mathrm{c}} \frac{[\mathrm{d} \mathbf{l} \mathbf{r}]}{\mathrm{r}^{3}} .
$$

The total field is determined by integrating expressions (3) and (4) over all values of the currents

$$
\mathbf{B}=\frac{1}{\mathrm{c}} \int \frac{[\mathbf{j r}]}{\mathrm{r}^{3}} \mathrm{dV}
$$

$$
\mathbf{B}=\oint \frac{\mathrm{I}}{\mathrm{c}} \frac{[\mathrm{d} \mathbf{l} \mathbf{r}]}{\mathrm{r}^{3}} .
$$

Relations (5) and (6) are valid for the case when direct currents flow in the conductors, which is implemented in the design of the U-2M torsatron.

Within the framework of the developed model, the coordinates of the geometric centers of the four halfpoles of the screw winding are determined.

These data are used in calculating the ponderomotive forces acting on the helical winding in the model consideration of currents concentrated in four current filaments corresponding to the half-poles.

Calculations of electrodynamic forces and their components were performed on the MathCad14 platform in the form shown in Fig. 8 coordinate system and are shown in Figs. 9-14. 

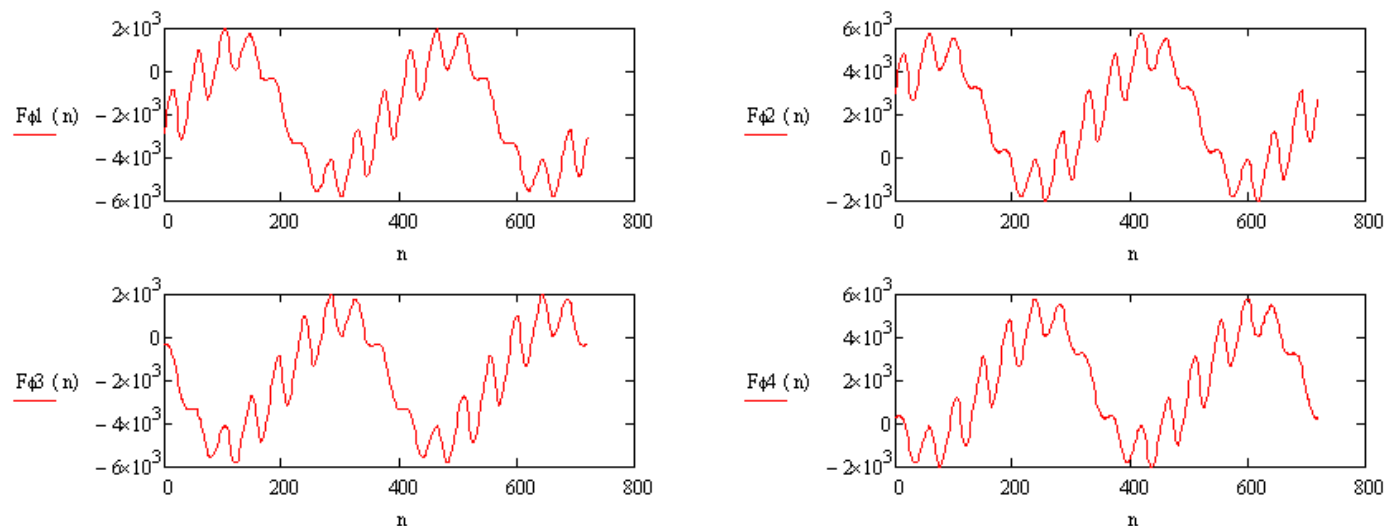

Fig. 10. Dependence of the component $\vec{F}_{\varphi}$ on the number of the discrete element of each SW half-pole
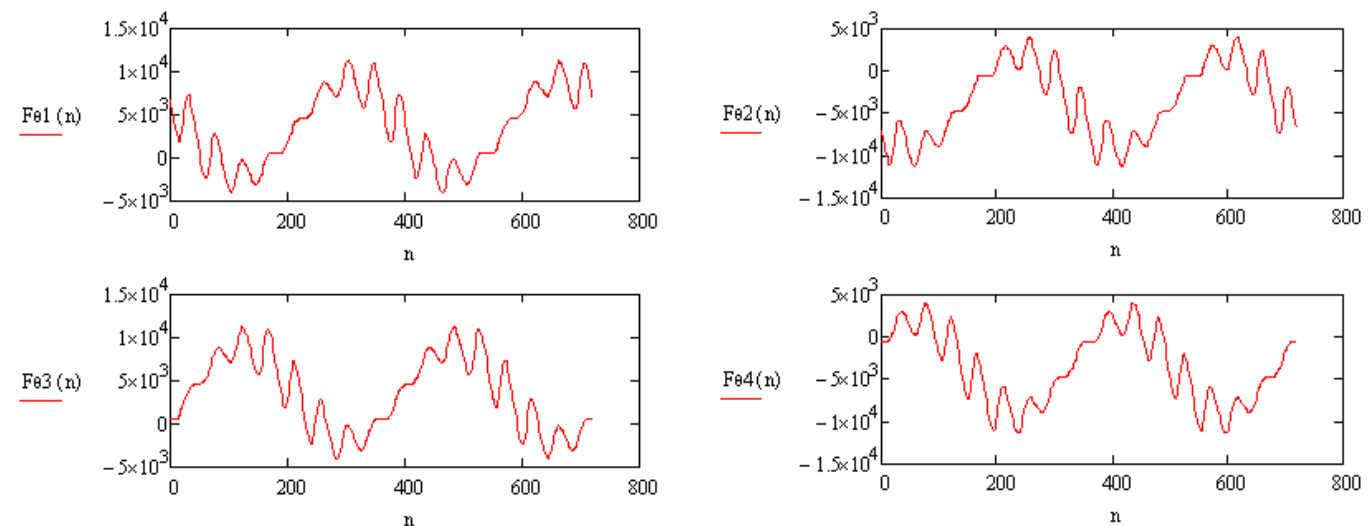

Fig. 11. Dependence of the component $\vec{F}_{\theta}$ on the number of the discrete element of each SW half-pole
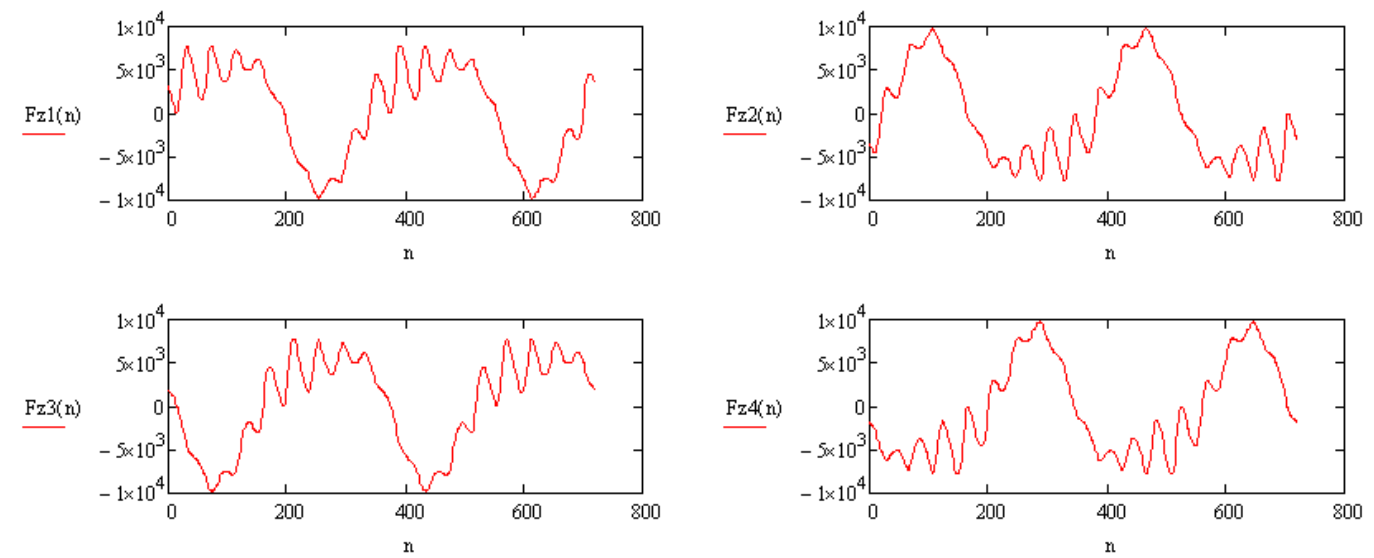

Fig. 12. Dependence of the component $\vec{F}_{z}$ on the number of the discrete element of each SW half-pole
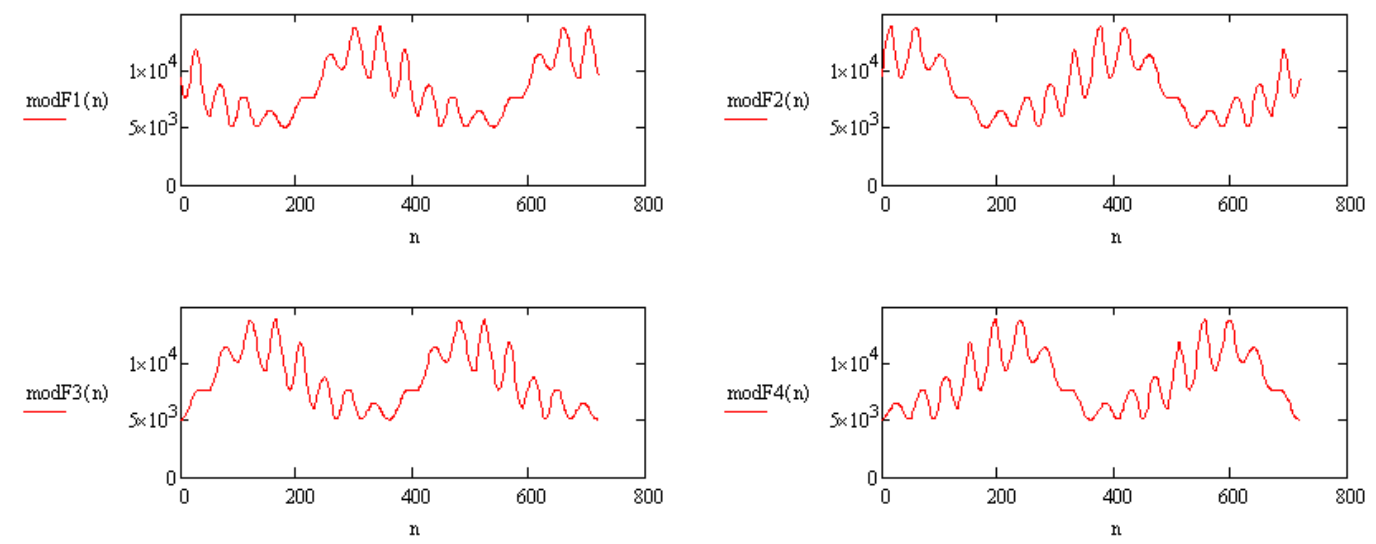

Fig. 13. Dependence of the modulus of the electrodynamic force on the number of the discrete element of each SW half-pole 

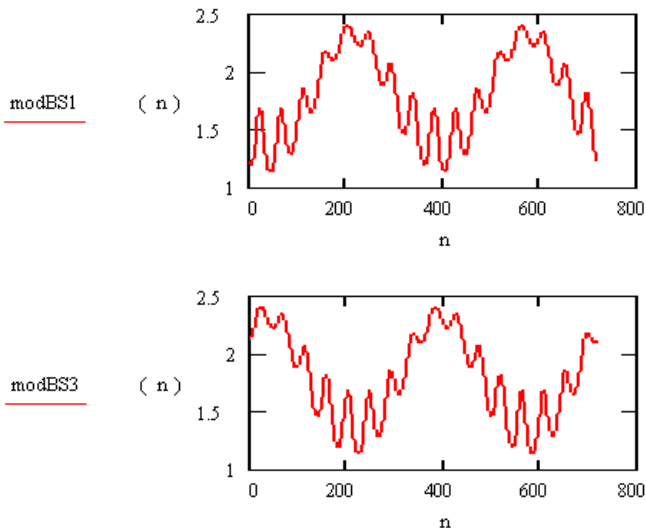
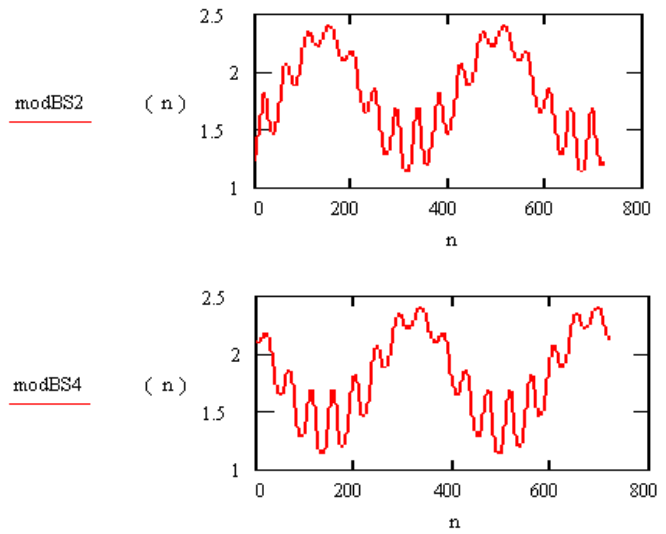

Fig. 14. Dependence of the modulus of the magnetic field induction vector on the number of the discrete element of each SW half-pole

\section{CONCLUSIONS}

The paper presents mathematical models, methods and algorithms for three-dimensional modeling of the screw winding of the U-2M torsatron. The use of the kinematic modeling method is substantiated as a basic method of geometric modeling. To obtain the SW threedimensional model, a set of meridional sections of the SW located on the torus was used as a drawing curve, followed by the formation of a raster and the restoration of coordinates on the simulated surface using a Bezier spline.

Models and methods for calculating stresses and strains arising in the elements of the magnetic system of a screw winding under the influence of ponderomotive forces are presented. The calculation is carried out on the basis of the theory of electromagnetic interactions. The performed calculations make it possible to determine the strength of the structural elements of the U-2M installation.

\section{REFERENCES}

1. E.D. Volkov, V.A. Suprunenko, A.A. Shishkin. Stellarator. Kiev: "Naukova Dumka", 1983, 310 p. (in Russian).

2. V.M. Chernen'kiy. Imitatsionnoye modelirovaniye. M.: "Vyssh. shk.", 1990 (in Russian).

3. R. Gallager. Metod konechnykh elementov. Osnovy. M.: "Mir", 1984 (in Russian).

4. M.B. Shubin. Kompleks program formirovaniya poverkhnostey. M.: "VTS AN SSSR", 1979, 102 p. (in Russian).

5. I.Ye. Irodov. Osnovnyye zakony elektromagnetizma. M.: "Vyssh. shk.", 1991 (in Russian).

Article received 31.05.2021

\section{МОДЕЛИ, МЕТОДЫ И ТЕХНОЛОГИИ РАСЧЕТА ХАРАКТЕРИСТИК ФИЗИЧЕСКОЙ УСТАНОВКИ УРАГАН-2М}

\section{С.А. Мартынов, А.А. Лучанинов, В.П. Лукьянова, М.А. Хажмурадов, С.И. Прохорец}

Рассмотрены модели, методы и алгоритмы трехмерного моделирования винтовой обмотки торсатрона Ураган-2М. Обосновано применение метода кинематического моделирования как наиболее приемлемого для получения твердотельной и поверхностной моделей элементов магнитной системы. Приведены методы расчета напряжений и деформаций, возникающих в элементах магнитной системы винтовой обмотки под воздействием пондеромоторных сил, что дает возможность определить прочность элементов конструкции установки.

\section{МОДЕЛІ, МЕТОДИ І ТЕХНОЛОГІЇ РОЗРАХУНКУ ХАРАКТЕРИСТИК ФІЗИЧНОЇ УСТАНОВКИ УРАГАН-2М}

\section{С.О. Мартинов, О.О. Лучанінов, В.П. Лук'янова, М.А. Хажжурадов, С.І. Прохорець}

Розглянуто моделі, методи і алгоритми тривимірного моделювання гвинтової обмотки торсатрона Ураган-2М. Обгрунтовано застосування методу кінематичного моделювання як найбільш прийнятного для отримання твердотільної і поверхневої моделей елементів магнітної системи. Наведено методи розрахунку напружень і деформацій, що виникають в елементах магнітної системи гвинтової обмотки під впливом пондеромоторних сил, що дає можливість визначити міцність елементів конструкції установки. 